\title{
Effect of filter media and hydraulic retention time on the performance of vertical constructed wetland system treating dairy farm wastewater
}

\author{
Deepa Minakshi ${ }^{1}$, Pradeep Kumar Sharma ${ }^{1^{\dagger}}$, Anju Rani ${ }^{2}$ \\ ${ }^{1}$ Department of Environmental Science, Graphic Era Deemed to be University, Dehradun, Uttarakhand, 248002, India \\ ${ }^{2}$ Department of Life Sciences, Graphic Era Deemed to be University, Dehradun, Uttarakhand, 248002, India
}

\begin{abstract}
This study deals with the dairy wastewater treatment using laboratory scale vertical flow (VF) constructed wetlands with the Canna indica plantation over wetland beds due to phytoremediation capabilities. Three laboratory scale VF CWs (CW-A, CW-B and CW-C) each with an area of 0.135 $\mathrm{m}^{2}$ filled with gravel (CW-A: $20 \mathrm{~mm}$; CW-B:10 mm gravel) and sand (CW-C) receiving $0.04 \mathrm{~m}^{3} \mathrm{~d}^{-1}$ dairy wastewater were operated for the wastewater purification. Each unit was operated at three hydraulic retention times (HRTs) i.e. $12 \mathrm{~h}, 24 \mathrm{~h}$ and $48 \mathrm{~h}$ for assessing its effect on wastewater purification . Among all units, removal rates fluctuated as: total suspended solids (TSS): $64.2-74.5 \%$; biochemical oxygen demand (BOD): 45.3 - 63.1\%; ammonium nitrogen $\left(\mathrm{NH}_{4}-\mathrm{N}\right): 29.6-56.5 \%$ and phosphate phosphorous $\left(\mathrm{PO}_{4}-\mathrm{P}\right): 20.5-57.8 \%$ at different HRTs. Increase in HRT showed better removal of pollutants in all CWs. Moreover, maximum removal of pollutants excluding TSS and $\mathrm{NH}_{4}-\mathrm{N}$ was achieved in $\mathrm{CW}-\mathrm{B}$ at $48 \mathrm{~h}$ HRT. CW-B with similar HRT provided maximum removal of $\mathrm{PO}_{4}-\mathrm{P}(57.8 \%)$, BOD (63.1\%) and chemical oxygen demand (COD): $67.4 \%$. Increase in the size of filter media, from sand $(0.25 \mathrm{~mm})$ to $20 \mathrm{~mm}$ gravel resulted in higher removal of $\mathrm{NH}_{4}-\mathrm{N}$ from wastewater.
\end{abstract}

Keywords: Artificial wetlands, Constructed Wetland (CW) System, Dairy wastewater, Hydraulic Retention Time (HRT), Treatment wetlands, Wastewater Purification

\section{Introduction}

Dairy farm practices release a huge volume of wastewater into the surrounding environment [1]. This wastewater is a mixture of animal urine, spilled milk, floor and utensil washings, traces of animal dung etc. It consists of small to medium strength of organic matter, phosphorous and nitrogen which is responsible for the problems of eutrophication in the receiving water bodies and degradation of soil quality as well [2]. In the past, many treatment techniques such as application of organic coagulants [3], advanced oxidation processes, membrane technology, anaerobic digestion [4], activated sludge process, trickling filters, rotating biological contractor, oxidation pond, UV disinfection, etc. have been tested for removing pollutants from dairy wastewater but only limited technologies could be successfully adopted. However long term use of these technologies was impaired due to high treatment cost, skilled labor, problem of sludge disposal, etc. Constructed Wetland (CW) technology is a convenient and eco-friendly alternative which is well suited for treating such kinds of wastewater [5]. Moreover, this technology has added advantages of; low treatment cost, better performance for removal of organic substances and nutrients like $\mathrm{N}, \mathrm{P}$ along with ability to tolerate load fluctuations in influent [6].

Constructed wetlands (CWs) are engineered systems that have been designed and used to utilize the natural processes involving wetland vegetation, soils, and associated microbial assemblages to assist in wastewater treatment [7]. Among the different designs of CWs, Horizontal, Vertical and Hybrid systems are the most common and had shown effective results in terms of pollutant removal from wastewater [8]. Construction of a CW system, involves consideration of many design parameters such as influent quality, desired effluent quality, organic dosing rate, selection of appropriate filter
This is an Open Access article distributed under the terms of the Creative Commons Attribution Non-Commercial License (http://creativecommons.org/licenses/by-nc/3.0/) which permits unrestricted non-commercial use, distribution, and reproduction in any medium, provided the original work is properly cited.

Copyright (C) 2022 Korean Society of Environmental Engineers
Received August 03, 2020 Accepted January 06, 2021

${ }^{\dagger}$ Corresponding author

E-mail: pradeep2910@gmail.com

Tel: +91-135-2643421

ORCID: 0000-0003-3750-5849 
material and macrophytes, hydraulic retention time (HRT), $\mathrm{BOD} / \mathrm{P} / \mathrm{N}$ ratio, bed depth, arrangement of beds (parallel or series) and surface partition at bed surfaces [9]. In VF CW system, filter media and plants play an important role in P removal [10]. These potent filter media such as sand and gravels have the capacity to bind phosphate and thus precipitate the phosphate content from wastewater. Along with this, plant such as Arundo donax absorb the readily available phosphate which are attached to the filter media surface [11].

The present study focusses on the removal of pollutants i.e. $\mathrm{NH}_{4}-\mathrm{N}$, TSS, $\mathrm{PO}_{4}-\mathrm{P}, \mathrm{BOD}$ and COD using laboratory scale vertical flow CW systems filled with different filter materials and operated at different HRTs for the treatment of dairy farm waste water. The CW system were planted with Cana indica owing to previous studies with similar plant, easy availability, price and aesthetic values [12].

\section{Materials and Methods}

\subsection{Study Site and Construction of Vertical Flow CW Systems}

The present study was conducted at Graphic Era University, Dehradun $\left(30.3165^{\circ} \mathrm{N}, 78.0322^{\circ} \mathrm{E}\right)$, Uttarakhand, India. Laboratory scale CW systems were built using round shaped plastic container with a depth of $50 \mathrm{~cm}$ (surface area: $0.135 \mathrm{~m}^{2}$ ). Three such containers were labelled as CW-A, B, C filled with $20 \mathrm{~mm}$ gravel, $10 \mathrm{~mm}$ gravel and sand, respectively. On the surface of each CW Cana indica was planted. Canna indica plant has phytoremediating properties and can easily grow in wet and marshy regions. Arrangement of sampling was made at the bottom of each container using a water tap (Fig. 1).

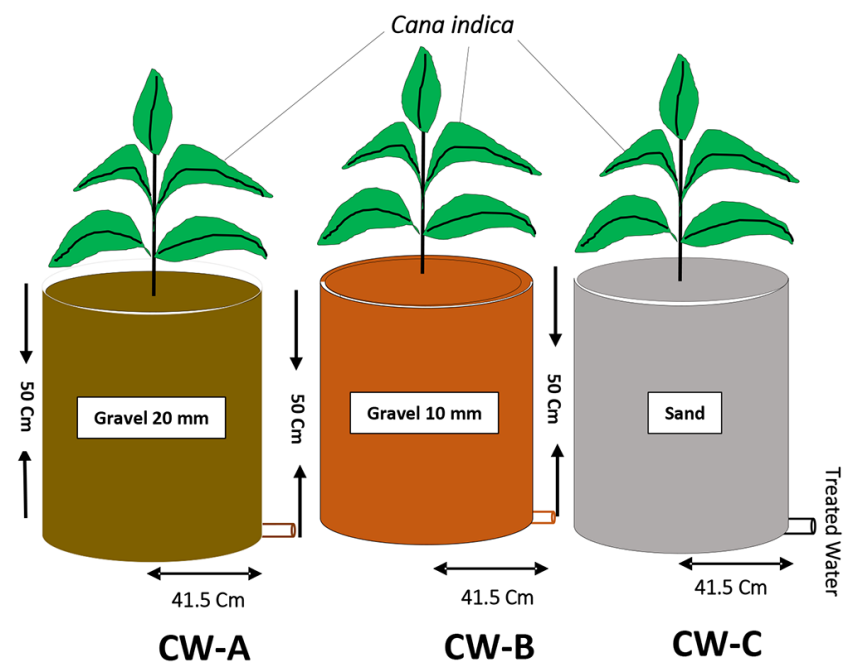

Fig. 1. Layout of CW-A, CW-B and CW-C for treatment of dairy farm wastewater.

\subsection{Filter Materials}

As per previous studies, different filter materials such as gravels of varied sizes, sand, etc. may be used in a CW unit [13]. Sand, being fine in size acts as the best filter material and treats waste- water using physical, biological and chemical processes [14] but is associated with problem of clogging. On the other hand, gravels too have its own advantages of excellent nitrification potential because of greater pore space for air availability and better adheration surface for microbial films which provides good mineralization of organic nitrogen and oxidation of ammonium ions [15]. This helps in maintaining aerobic conditions on the bed surfaces which supports the pollutant removal processes. Moreover, the gravel filled systems are less susceptible to clogging during their operation.

As the wastewater percolates slowly through the filter material, various physical, biological and chemical processes occur in combination resulting in the removal of pollutants from wastewater. Phosphorous gets attached to sand /gravel surface resulting in adsorption and precipitation processes in the CW unit [15]. These filter materials act like a natural home for variety of microbes such as Bacillus, Micrococcus, Pseudomonas etc. which contribute to organic matter degradation as well as nitrification and denitrification [16]. These filter materials serve as efficient units for removal of pollutants from wastewater (BOD, COD, $\mathrm{NH}_{4}-\mathrm{N}, \mathrm{PO}_{4}-\mathrm{P}$ and fecal coliforms).

\subsection{Hydraulic Retention Time (HRT)}

HRT is the most easily changed operational variable in the design of CW system [17]. The performance of a Constructed Wetland system largely depends on the selected HRT because it reflects a contact period between wastewater and the wetland system [18].

Previous studies by DeBusk and Reddy [19] and Kadlec and Knight [20], recommended that longer the contact period of water with the filter material inside the wetland, more removal of pollutants occurs. In the past many studies were conducted at different HRTs ( $8 \mathrm{~h}$ to $20 \mathrm{~d}$ ) (Table 1) However, most of these studies were focussed on the treatment of domestic wastewater. To the best of our knowledge, none of the study has been conducted for treatment of dairy farm wastewater at shorter HRTs.

Based on previous studies related to filter materials and HRT in CWs, this research work was designed to analyse the performance of laboratory scale vertical sub-surface flow Constructed Wetland systems operated with different filter material and HRTs and their combined effect on removal of organic and inorganic pollutants from dairy wastewater.

\subsection{Experimental Design and Collection of Samples}

Dairy wastewater samples were collected from dairy farm located nearby Graphic Era University, Dehradun Uttarakhand, India. In this study, different filter materials i.e. gravel of $10 \mathrm{~mm}$ and 20 $\mathrm{mm}$ sizes and sand were used in separate CW units (A, B and C). Canna indica plant was selected for surface plantation and was collected from a sewage drain located near Graphic Era University. Filter materials and the plants were brought to the laboratory and washed properly before starting the experiment. Plastic containers of depth $50 \mathrm{~cm}$ and diameter $41.5 \mathrm{~cm}$ each were taken for the experiment. $20 \mathrm{~mm}$ and $10 \mathrm{~mm}$ gravels were filled throughout the container A (CW-A) and container B (CW-B), respectively while container $\mathrm{C}(\mathrm{CW}-\mathrm{C})$ was filled from top to bottom with washed sand $(0.25 \mathrm{~mm})$. Control systems for all the three 
Table 1. Comparative Table Representing HRT Studies Carried Out by Various Researchers

\begin{tabular}{|c|c|c|c|c|c|c|c|c|c|c|}
\hline \multirow{2}{*}{ Reference } & \multirow{2}{*}{ Design } & \multirow{2}{*}{ Type of wastewater } & \multirow{2}{*}{ HRT } & \multicolumn{7}{|c|}{ Removal rate (\%) } \\
\hline & & & & BOD & COD & $\mathrm{PO}_{4}-\mathrm{P}$ & $\mathbf{T N}$ & $\mathrm{NH}_{4}-\mathrm{N}$ & $\mathrm{NO}_{3}-\mathrm{N}$ & TSS \\
\hline \multirow{2}{*}{ Thalla et al. [47] } & \multirow{2}{*}{ VF CW } & \multirow{2}{*}{ Domestic wastewater } & $12 \mathrm{~h}$ & 68 & 50 & 75 & - & 67.2 & 47.5 & - \\
\hline & & & $24 \mathrm{~h}$ & 83 & 65 & 90 & - & 84.4 & 66.8 & - \\
\hline Zhu et al. [49] & VFCW & Domestic wastewater & $48 \mathrm{~h}$ & & 85 & 77.9 & 89.9 & - & - & 81.2 \\
\hline Raphael et al. [48] & VFCW & Raw gray water & $3 \mathrm{~d}$ & 35.4 & 56.7 & 65 & 92 & - & - & 59.6 \\
\hline \multirow{3}{*}{ Stearman et al. [36] } & \multirow{3}{*}{ SSF CW } & \multirow{3}{*}{$\begin{array}{l}\text { Nursery irrigation } \\
\text { runoff }\end{array}$} & $0.7 \mathrm{~d}$ & - & - & 10.0 & 70.8 & - & - & - \\
\hline & & & $1.2 \mathrm{~d}$ & - & - & 7.7 & 71.8 & - & - & - \\
\hline & & & 1.9 & - & - & -1.7 & 69.9 & - & - & - \\
\hline Arias et al. [35] & SSF CW & Domestic sewage & $7 \mathrm{~d}$ & - & - & 45.6 & - & - & - & - \\
\hline \multirow{4}{*}{ Ghosh and Gopal [45] } & \multirow{4}{*}{ VF CW } & \multirow{4}{*}{$\begin{array}{l}\text { Dairy processing } \\
\text { industry wastewater }\end{array}$} & $1 \mathrm{~d}$ & 30.4 & 30.8 & 26.1 & 35.4 & 81.0 & 40.8 & 80.2 \\
\hline & & & $2 \mathrm{~d}$ & 69.6 & 72.2 & 55.6 & 80.5 & 92.9 & 85.8 & 90.2 \\
\hline & & & $3 \mathrm{~d}$ & 82.2 & 85.0 & 63.3 & 84.9 & 99.4 & 95.9 & 95.6 \\
\hline & & & $4 \mathrm{~d}$ & 93.9 & 97.1 & 92.7 & 94.6 & 92.7 & 98.6 & 98.8 \\
\hline \multirow{4}{*}{ Akratos and Tsihrintzis [30] } & \multirow{4}{*}{$\mathrm{HF}$ CW } & \multirow{4}{*}{ Synthetic wastewater } & $6 \mathrm{~d}$ & 87.9 & 88.7 & 29.3 & 44.8 & 19.1 & - & - \\
\hline & & & $8 \mathrm{~d}$ & 94.0 & 92.6 & 81.8 & 80.2 & 77.9 & - & - \\
\hline & & & $14 \mathrm{~d}$ & 91.2 & 92.8 & 90.3 & 78.9 & 74.9 & - & - \\
\hline & & & $20 \mathrm{~d}$ & 90.2 & 91.8 & 98.5 & 85.9 & 87.5 & - & - \\
\hline \multirow{3}{*}{ Sirianuntapiboon et al. [46] } & \multirow{3}{*}{$\mathrm{VF}$ (UF) CW } & \multirow{3}{*}{ Domestic wastewater } & $0.75 \mathrm{~d}$ & 88.0 & 84.0 & 84.0 & 63.0 & 30.0 & - & 42.0 \\
\hline & & & $1.5 \mathrm{~d}$ & 91.0 & 82.0 & 89.0 & 67.0 & 64.0 & - & 89.0 \\
\hline & & & $3 \mathrm{~d}$ & 91.0 & 90.0 & 93.0 & 84.0 & 62.0 & - & 76.0 \\
\hline \multirow{4}{*}{ Toet et al. [18] } & \multirow{4}{*}{ SF CW } & \multirow{4}{*}{ STP effluent } & $0.3 \mathrm{~d}$ & - & 3.5 & -4.5 & 14.3 & 16.9 & 21.2 & - \\
\hline & & & $0.8 \mathrm{~d}$ & - & 0.5 & -10.1 & 24.3 & 29.2 & 29.8 & - \\
\hline & & & $2.3 \mathrm{~d}$ & - & 0.9 & 5.4 & 41.4 & 65.1 & 44.0 & - \\
\hline & & & $9.3 \mathrm{~d}$ & - & -12.8 & 1.6 & 63.1 & 87.0 & 85.6 & - \\
\hline
\end{tabular}

CW systems were also considered for the study. The control CW systems had the same materials and other specifications as CW-A, CW-B and CW-C, but were operated at zero HRT unlike CW-A, CW-B and CW-C.

On the basis of retention time, flow rates, bed surface area and concentrations of organic matter and nitrogen, the decomposition constant coefficients $(k)$ for wastewater treated in VF beds were calculated. First order equation form presented in (Eq. (1)), which uses $k_{V}$ rate and the HRT for VF beds:

$$
C_{\text {out }} / C_{\text {in }}=\exp \cdot\left(-k_{A} / q\right)
$$

Here, $q=$ hydraulic loading rate in $\mathrm{m} \mathrm{d}^{-1}$ i.e. calculated as the ratio of flow rate $(Q)$ in $\mathrm{m}^{3} \mathrm{~d}^{-1}$ and surface area $(A)$ in $\mathrm{m}^{2}$ whereas $k_{A}$ is the decomposition constant in $\mathrm{m} \mathrm{d}^{-1}$ [21].

Forty litres of dairy farm wastewater was dosed intermittently (batch feeding mode) everyday to each container. Dairy influent was analyzed for $\mathrm{pH}$, ORP (oxidation reduction potential), EC (electrical conductivity), TDS (total dissolved solids), TSS (total suspended solids), salinity, DO (dissolved oxygen), temperature, BOD (biochemical oxygen demand), COD (chemical oxygen demand), $\mathrm{NH}_{4}-\mathrm{N}$ (ammonium-nitrogen), and $\mathrm{PO}_{4}-\mathrm{P}$ (phosphate phosphorous) before dosing to the CW systems. Treated samples from control beds and all the three systems were collected in 1 litre plastic bottles. These treated water samples were collected at specific HRTs $(0 \mathrm{~h}, 12 \mathrm{~h}$, $24 \mathrm{~h}$ and $48 \mathrm{~h}$ ) through the knob at the base of each container after HRT of $12 \mathrm{~h}, 24 \mathrm{~h}$ and $48 \mathrm{~h}$, respectively. The study was carried out for a period of three months (from March to May 2019).

\subsection{Analytical Procedures}

Regular samples were collected from the outlets of all the three containers after HRT of $0 \mathrm{~h}, 12 \mathrm{~h}, 24 \mathrm{~h}$ and $48 \mathrm{~h}$, respectively and stored in refrigerator for analysis. Samples from the control beds of all the three CW systems were collected at zero $h$ HRT i.e. no HRT was set in these beds. All the untreated and treated water samples were analysed in laboratory as per the guidelines of standard methods for examination of water and wastewater [22] and Hach Manual. pH, ORP, EC, TDS, salinity and temperature were analyzed during the study period by using multiparameter system (Hach SensION+ MM 150). DO was measured using DO meter (Hach SensION). Similarly, other parameters were measured using methods such as TSS (colorimetric method), BOD (3-d incubation method), COD (reactor digestion method), $\mathrm{NH}_{4}-\mathrm{N}$ (salicylate method) and $\mathrm{PO}_{4}-\mathrm{P}$ (molybdovanadate method).

\subsection{Determination of Removal Rate}

The efficiency of the vertical sub-surface constructed wetland system for removal of pollutants was calculated in terms of removal rate using the following equation [5]. 
Removal rate $(\%)=\left(C_{i}-C_{o}\right){ }^{*} 100 / C_{i}$

$C_{i}=$ Influent concentration ( $\left.m g L^{-1}\right)$;

$C_{o}=$ Effluent concentration (mg $\left.L^{-1}\right)$

\section{Results and Discussion}

\section{1. $\mathrm{pH}, \mathrm{DO}, \mathrm{NO}_{3}-\mathrm{N}$ and $\mathrm{NH}_{4}-\mathrm{N}$}

Average $\mathrm{pH}$ in the influent was recorded as $7.2 \pm 0.4$ which changed between $7.23 \pm 0.2$ in control, $7.3 \pm 0.3$ to $7.5 \pm 0.3$ in CW-A, $7.2 \pm 0.4$ to $7.5 \pm 0.2$ in CW-B and $7.4 \pm 0.3$ to $7.7 \pm 0.2$ in CW-C unit (Table S1). Although no significant change in $\mathrm{pH}$ was observed at different HRTs yet maximum $\mathrm{pH}$ change was observed at $48 \mathrm{~h} \mathrm{HRT}$ in all CW systems. Average DO concentration in the influent was found to be $4.3 \pm 2.0 \mathrm{mg} \mathrm{L}^{-1}$. The control bed of CW-A showed a fluctuation of 2.9 to $4.9 \mathrm{mg} \mathrm{L}^{-1}$ during the study period while in CW-B control bed, it ranged between 3.0 to $5.0 \mathrm{mg} \mathrm{L}^{-1}$. The control bed of $\mathrm{CW}-\mathrm{C}$ showed minimum and maximum DO values of 2.9 and $4.9 \mathrm{mg} \mathrm{L}^{-1}$, respectively. In the treated water, DO was recorded in the range of $4.9 \pm 0.35$ to 5.8 $\pm 0.8 \mathrm{mg} \mathrm{L}^{-1}$ among all CW systems. CW B (10 mm gravel filled unit) showed $4.9 \pm 0.35,5.0 \pm 0.6$ and $5.2 \pm 0.2 \mathrm{mg} \mathrm{L}^{-1}$ average DO concentrations at HRTs 0, 12, 24 and 48 h, respectively (Fig. 2). A slightly higher DO increase $\left(5.1 \pm 0.5\right.$ to $\left.5.8 \pm 0.8 \mathrm{mg} \mathrm{L}^{-1}\right)$ was observed in CW-A (20 mm gravel filled) and CW-C i.e. sand filled unit $\left(5.1 \pm 0.6\right.$ to $5.4 \pm 0.7 \mathrm{mg} \mathrm{L}^{-1}$ ). The percent DO increase at outlets w.r.t influent DO concentration was observed as 34.9 and $25.6 \%$ in CW-A and CW-C respectively at $24 \mathrm{~h} \mathrm{HRT}$ and $20.9 \%$ in CW-B at $48 \mathrm{~h}$ HRT. Maximum DO increase of $5.8 \mathrm{mg} \mathrm{L}^{-1}$ was
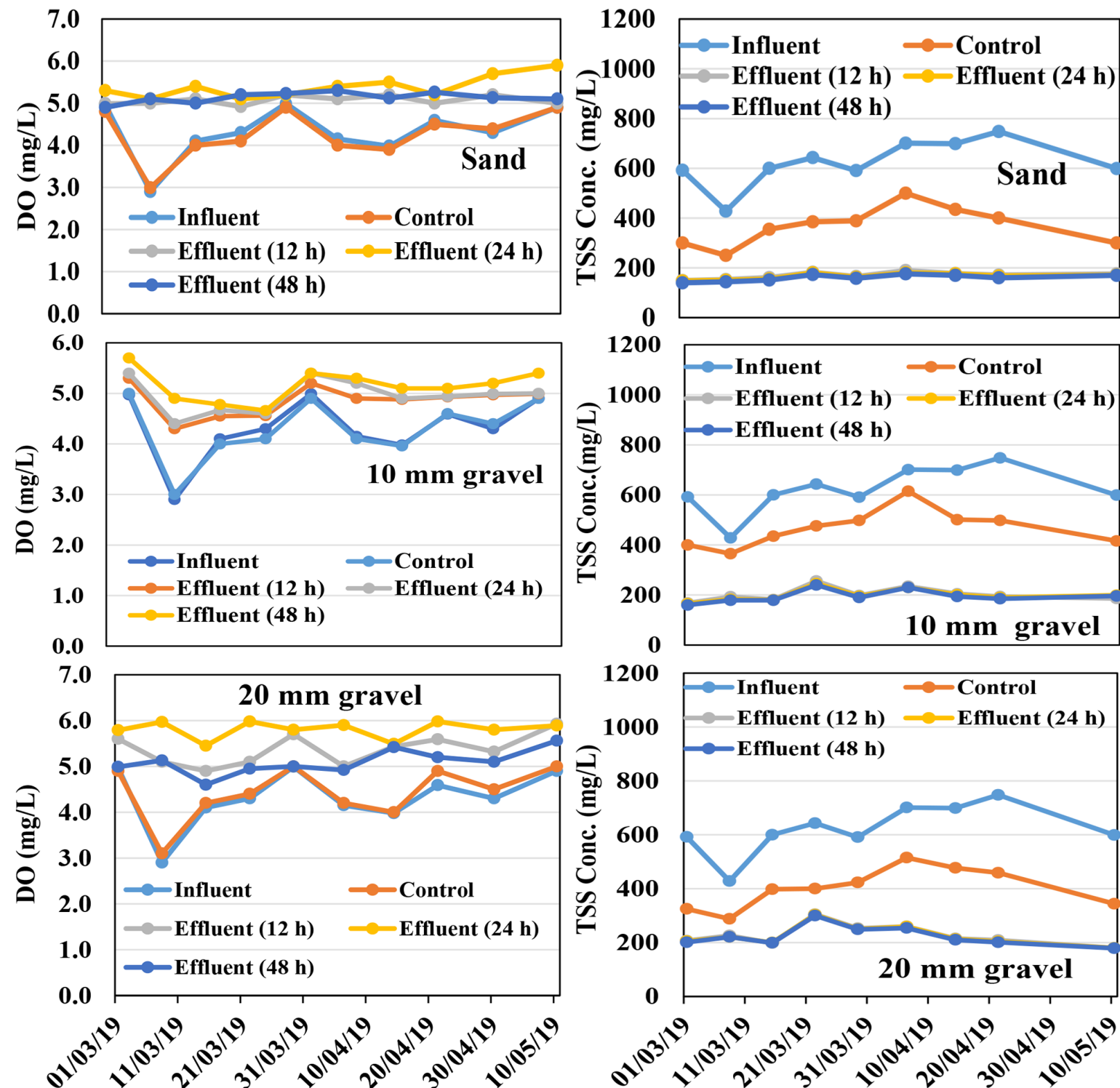

Fig. 2. Continuous DO and TSS concentrations in influent and effluent in control, CW-A, CW-B and CW-C during the study period. 
recorded in $20 \mathrm{~mm}$ gravel filled system at an HRT of $24 \mathrm{~h}$.

Nitrification is a key characteristic of vertical flow systems [23]. The influent showed an average $\mathrm{NO}_{3}-\mathrm{N}$ concentration of $1.5 \pm$ $0.8 \mathrm{mg} \mathrm{L}^{-1}$. Effluents of control and all the CW systems showed higher $\mathrm{NO}_{3}-\mathrm{N}$ concentrations; $2.1 \pm 0.5-3.0 \pm 0.3 \mathrm{mg} \mathrm{L}^{-1}$ in CW-A, $1.8 \pm 0.3-3.7 \pm 0.4 \mathrm{mg} \mathrm{L}^{-1}$ in CW-B and $1.7 \pm 0.3-1.98 \pm 0.5$ mg L $\mathrm{L}^{-1}$ in CW-C. In all the CW systems $\mathrm{NO}_{3}-\mathrm{N}$ concentration showed an increase (42.9\% in CW-A, 32.1\% in CW-B and $13.1 \%$ in CW-C) when HRT was increased from $12 \mathrm{~h}$ to $24 \mathrm{~h}$ however, when HRT was further extended to $48 \mathrm{~h}$, the $\mathrm{NO}_{3}-\mathrm{N}$ concentration showed a decrease in effluent (Table S1). This might be due to denitrification process which occurs at longer HRTs. It has also been reported that at longer HRT a well-developed microbial community in CWs gets suitable contact time to remove pollutants [24, 25]. In a study by Toet et al. [25] positive nitrogen removal was observed in CWs
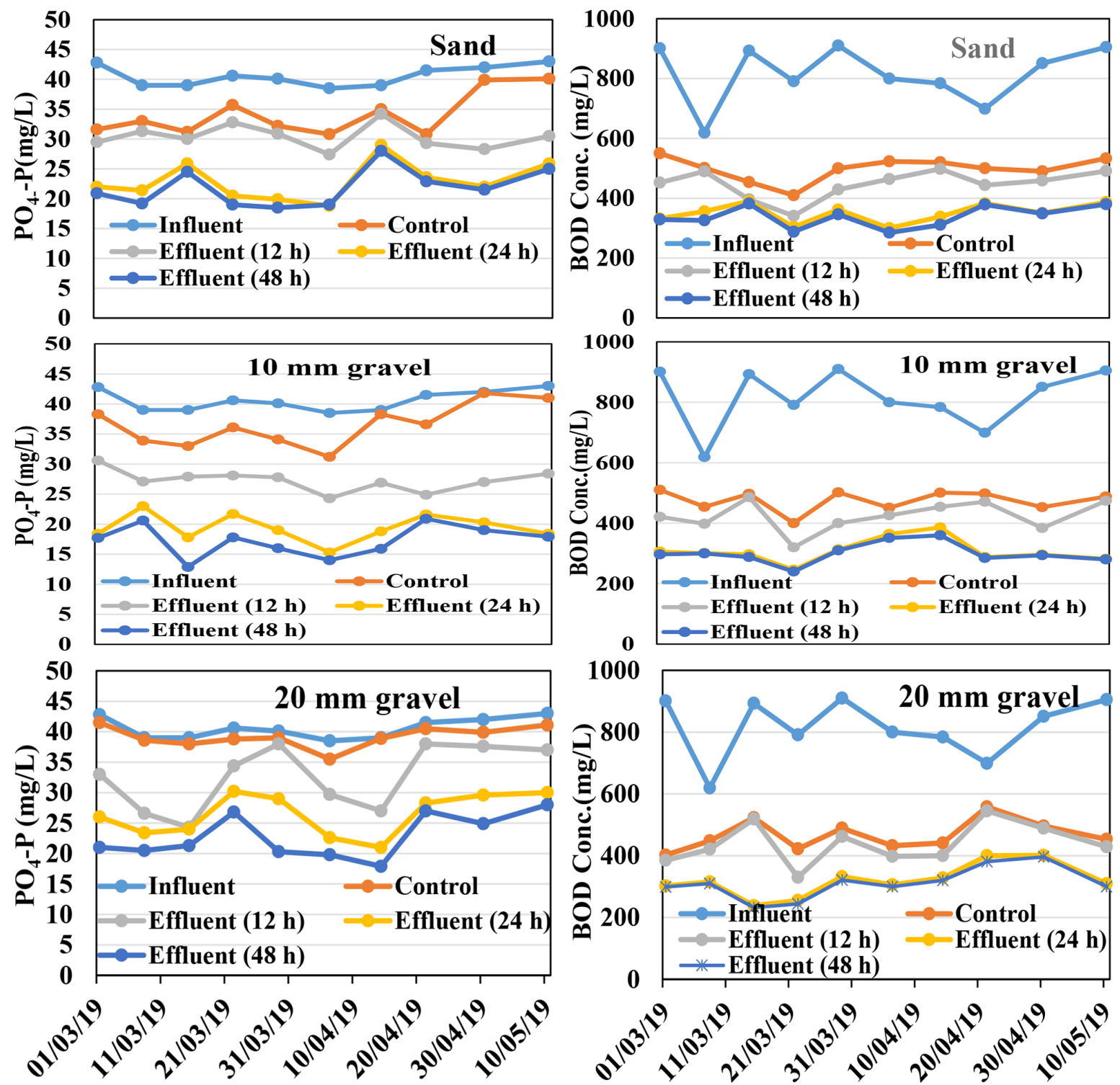

Fig. 3. Continuous $\mathrm{PO}_{4}-\mathrm{P}$ and $\mathrm{BOD}$ concentrations in influent and effluent in control, CW-A, CW-B and CW-C during the study period. 
recorded as $29.1 \pm 3.7,24.3 \pm 4.0$ and $25 \pm 2.5 \mathrm{mg} \mathrm{L}^{-1}$ at HRTs 12, 24 and $48 \mathrm{~h}$ (Table S1). The $\mathrm{NH}_{4}-\mathrm{N}$ concentrations in the control beds of CW-A, CW-B and CW-C fluctuated between 29.1 to 38.1 $\mathrm{mg} \mathrm{L}^{-1}, 33.1$ to $41.4 \mathrm{mg} \mathrm{L}^{-1}$ and 39.6 to $45.2 \mathrm{mg} \mathrm{L}^{-1}$, respectively (Fig. 4). During its retention insided the wetland bed, water undergoes certain physical, chemical and biological processes which leads to removal of toxic pollutants like ammonium, nitrogen, suspended solids and phosphate. The major processes involved in removal of ammonium nitrogen in a CW are nitrification-denitrification [27]. Nitrogen removal in constructed wetland depends upon environmental parameters (e.g. $\mathrm{pH}$, oxygen, temperature etc.), operating conditions (hydraulic and pollutant loading, detention
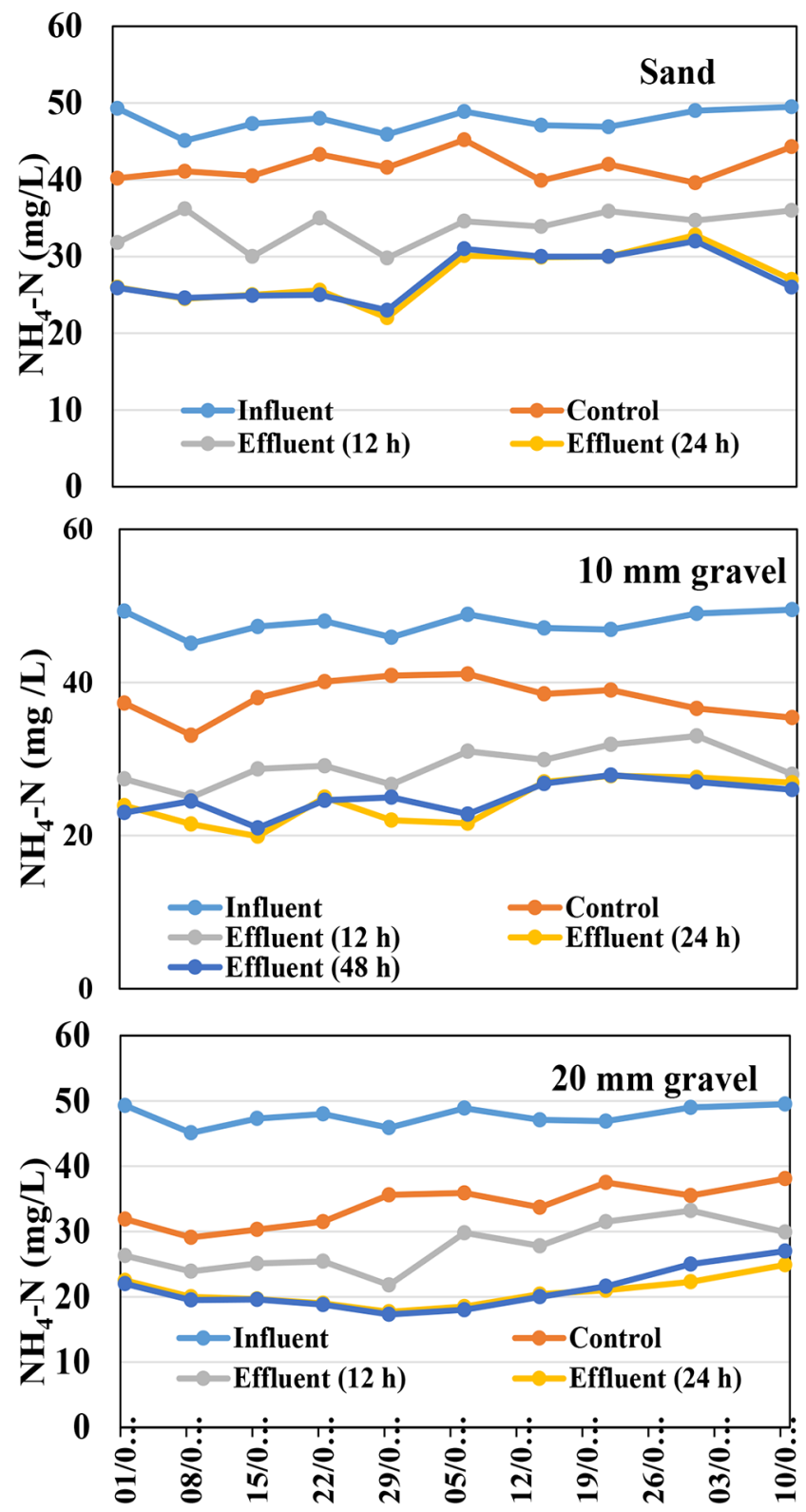

Fig. 4. Continuous $\mathrm{NH}_{4}-\mathrm{N}$ concentrations in influent and effluent in control, CW-A, CW-B and CW-C during the study period.

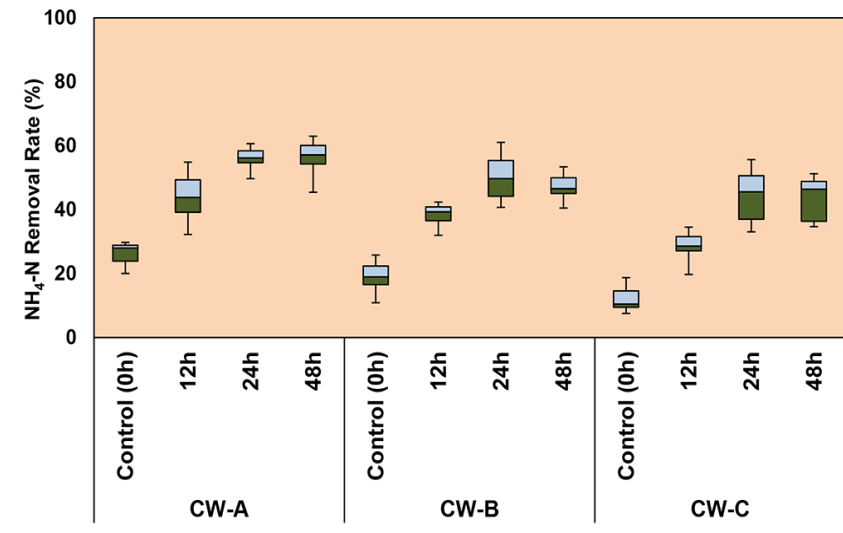

Fig. 5. $\mathrm{NH}_{4}-\mathrm{N}$ removal rates at different HRTs in VF CW. system.

time, influent feed mode, recirculation, organic carbon addition etc.) and presence of microorganisms [24]. Among these parameters HRT plays an important role as it affects the contact duration between microbes and pollutants [28]. In this study, CW-A unit provided $43.8 \%$ removal of $\mathrm{NH}_{4}-\mathrm{N}$ at $12 \mathrm{~h}$ HRT which was subsequently increased to 56.3 and $56.5 \%$ at $24 \mathrm{~h}$ and $48 \mathrm{~h}$ HRTs. In CW-B unit (10 mm gravel filled), average removal percentage was recorded as $39.4 \%$ at $12 \mathrm{~h} \mathrm{HRT}$, further showed an increase of nearly $10 \%$ on extending HRT to $24 \mathrm{~h}$. However no further increased was observed in $\mathrm{NH}_{4}-\mathrm{N}$ removal when HRT was taken to $48 \mathrm{~h}$ (Fig. 5). More or less similar trend was observed in sand filled unit, CW-C which provided $29.6 \% \mathrm{NH}_{4}-\mathrm{N}$ removal at 12 $\mathrm{h}$ HRT. This was further increased to $43.1 \%$ and $43.8 \%$ at $24 \mathrm{~h}$ and 48 h HRTs, respectively. In a similar study [29], with field scale VF CW system (20 mm gravels), the removal of $\mathrm{NH}_{4}-\mathrm{N}$ was more (75\% removal in $24 \mathrm{~h} \mathrm{HRT)}$ ) as compared to lab-scale VF CW system filled with $20 \mathrm{~mm}$ gravels (56.3\% in $24 \mathrm{~h}$ ). Our results are not in an agreement with a previous study carried out by Akratos and Tsihrintzis [30] in which the overall removal of $\mathrm{NH}_{4}-\mathrm{N}$ was achieved as 74.9 and $87.5 \%$ at HRTs of 14 and $20 \mathrm{~d}$, respectively. The differences in result may be due to variation in HRTs of both studies which were $0-48 \mathrm{~h}$ in our study against $14-20 \mathrm{~d}$ in the compared study.

\subsection{TSS and $\mathrm{PO}_{4}-\mathrm{P}$}

Total suspended solids (TSS) are the substances of size $>2$ microns and are present in the form of inorganic materials, though dust, bacteria, algae etc. may also contribute to total solid concentration in water [31,32]. The average concentration of suspended solids in dairy influent was recorded as $628.0 \pm 53.0 \mathrm{mg} \mathrm{L}^{-1}$ (Table S1). The control beds of CW-A and CW-B showed fluctuations in TSS concentration from 288.0 to $515.0 \mathrm{mg} \mathrm{L}^{-1}$ and 365.0 to $615.0 \mathrm{mg}$ $\mathrm{L}^{-1}$, respectively whereas in sand control beds, fluctuation of 250.0 to $500.0 \mathrm{mg} \mathrm{L}^{-1}$ was recorded (Fig. 2). Gravel $(20 \mathrm{~mm})$ in CW-A showed a removal of $64.2 \%$ of TSS at $12 \mathrm{~h}$ HRT which showed more or less similar removal rate when HRT was increased to to $24 \mathrm{~h}$ HRT. Likewise, no further increase in removal rate was observed at $48 \mathrm{~h}$ HRT (Fig. 6). Gravel (10 mm) in CW-B unit also showed silimar pattern with $67.9 \%$ removal at $12 \mathrm{~h}$ and $68.4 \%$ at $24 \mathrm{~h} \mathrm{HRT}$. No further increase in the removal rate was seen at $48 \mathrm{~h} \mathrm{HRT}$. Sand showed maximum removal of suspended solids 


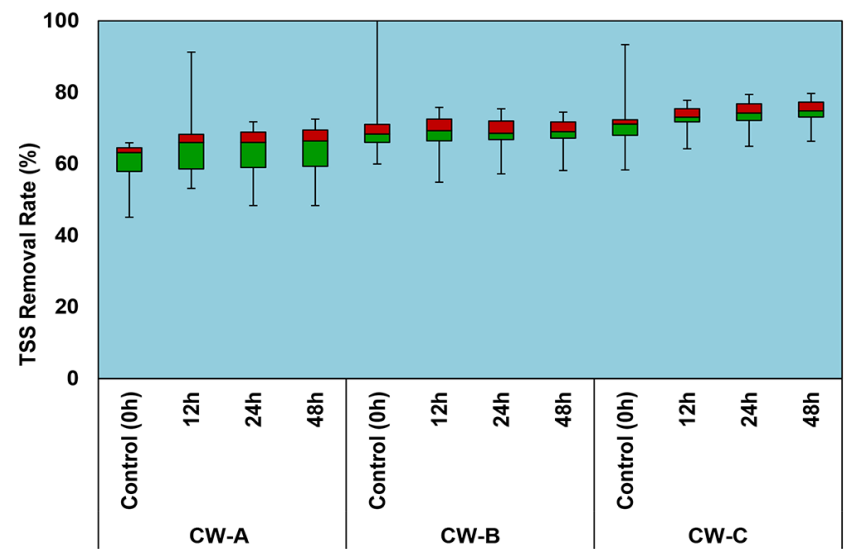

Fig. 6. TSS removal rates at different HRTs in VF CW system.

(73.1-74.5\%) at all HRTs in CW-C because sand acts as a fine filter medium and is capable to remove small to large size suspended particles from the wastewater (Fig. 5). Vymazal [33] in one of his study recorded $75 \%$ removal of suspended solids using gravel media as substrate. Another studies suggested that TSS removal is mainly a physical process and is also affected by retention time [34-36] but in our study, HRT did not produce a significant change in the TSS removal capacity of all three CW units. However, substrates play a very vital role in TSS removal as recorded in the study conducted by Manios et al. [37] in which removal percentage of TSS was found to be 85 and $90 \%$ in gravel and sand respectively. In our study, sand filter with $48 \mathrm{~h}$ HRT arrangement was found to be most suitable for achieving maximum (74.5\%) TSS removal from the waste water.

Phosphorous in wetlands occurs as phosphate in organic and inorganic compounds. In a wetland system, P removal occurs by adsorption and precipitation mechanisms. The $\mathrm{P}$ present in the wastewater usually gets bind to the filter substrates of the CW beds as a result of adsorption and precipitation reactions by combining with the $\mathrm{Ca}, \mathrm{Al}$ and $\mathrm{Fe}$ present in the gravel or sand substrates [31]. Thus the ability of VF CW beds to reduce $\mathrm{P}$ is dependent on the contents of these minerals in the filter media. Other factors like plant uptake and biological reactions do not play major role in $\mathrm{P}$ removal [31]. Thus, filter media has an important role in removing phosphorus from wastewater. $\mathrm{PO}_{4}-\mathrm{P}$ in influent has an average concentration of $41.0 \pm 4.7 \mathrm{mg} \mathrm{L}^{-1}$. In the control system of CW-A and CW-B, the $\mathrm{PO}_{4}-\mathrm{P}$ concentration was found to be fluctuating between 35.5 to 41.5 and 31.2 to $41.8 \mathrm{mg} \mathrm{L}^{-1}$, respectively while in sand (CW-C) control bed, it was recorded to range from 30.8 to $40.1 \mathrm{mg} \mathrm{L}^{-1}$ (Fig. 3). Average $\mathrm{PO}_{4}-\mathrm{P}$ concentration at the outlet of CW-A was recorded as; $32.6 \pm 4.8 \mathrm{mg} \mathrm{L}^{-1}$ at $12 \mathrm{~h}, 26.4$ $\pm 3.6 \mathrm{mg} \mathrm{L}^{-1}$ at $24 \mathrm{~h}$ and $22.8 \pm 2.9 \mathrm{mg} \mathrm{L}^{-1}$ at $48 \mathrm{~h}$ HRT (Table S1). In CW-A (20 mm gravel filled unit), removal rate of $\mathrm{PO}_{4}-\mathrm{P}$ was observed as $20.5 \%$ at $12 \mathrm{~h}$ HRT. An increment of $15.1 \%$ was recorded at $24 \mathrm{HRT}$ resulting in $36.6 \%$ removal. On further increasing HRT to $48 \mathrm{~h}, \mathrm{PO}_{4}-\mathrm{P}$ removal rate was increased upto $44.4 \%$. In CW-B (10 mm gravel filled unit), average $\mathrm{PO}_{4}-\mathrm{P}$ concentration in treated water was observed as; $27.3 \pm 4.4,19.4 \pm 3.6$ and 17.3 $\pm 3.3 \mathrm{mg} \mathrm{L}^{-1}$ at 12,24 and $48 \mathrm{~h}$ HRTs, respectively. The average removal rate was recorded as $33.4 \%$ at $12 \mathrm{~h} \mathrm{HRT;} 52.7 \%$ at $24 \mathrm{~h}$

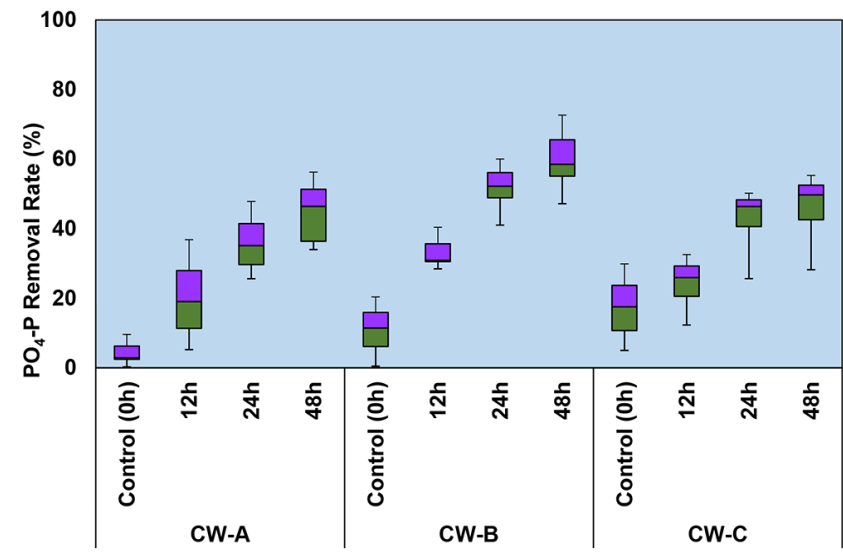

Fig. 7. $\mathrm{PO}_{4}-\mathrm{P}$ removal rates at different HRTs in VF CW system.

HRT and further an increase of $5.1 \%$ at $48 \mathrm{~h}$ (Fig. 7). In CW-C (Sand filled unit), $\mathrm{PO}_{4}-\mathrm{P}$ removal rates was recorded as 25.9, 44.1 and $46.1 \%$ at $12 \mathrm{~h}, 24 \mathrm{~h}$ and $48 \mathrm{~h}$ HRTs, respectively (Fig. 7). Among all the three CW units, CW-B (10 mm gravel filled unit) showed maximum removal of $\mathrm{PO}_{4}-\mathrm{P}$ at $48 \mathrm{~h}$ HRT. Phosphorous removal mainly takes place by absorption by plants and sorption processes on the media used, and this phosphorous can be stored in the accumulated sediments [32]. Seo et al. [32], in his study, explained that $\mathrm{P}$ may remain bound to the media components as a result of precipitation and adsorption reactions with ions $(\mathrm{Ca}, \mathrm{Fe}$ or $\mathrm{Al}$ ) present in sand or gravels. The particle size of substrates which are suitable for P removal may vary significantly.

Our results showed a higher $\mathrm{PO}_{4}-\mathrm{P}$ removal as compared to a study conducted by Arias et al. [35] in which the maximum removal $(45.6 \%)$ of $\mathrm{PO}_{4}-\mathrm{P}$ wasachieved at HRT of $7 \mathrm{~d}$. In another study conducted by Stearman et al. [36], maximum $\mathrm{PO}_{4} \mathrm{P}$ removal was recorded as $10 \%$ at 0.7 day HRT.

\section{3. $\mathrm{BOD}_{3}$ and $\mathrm{COD}$}

Biochemical Oxygen Demand (BOD) determines the amount of oxygen required by the biological organisms to degrade organic pollutants. It is a pollution indicating parameter. The average $\mathrm{BOD}_{3}$ value found in the dairy influent was $815.0 \pm 33 \mathrm{mg} \mathrm{L}^{-1}$ (Table S1). The BOD value in control beds of CW-A and CW-B fluctuated from 402.0 to 558.0 and 400.0 to $510.0 \mathrm{mg} \mathrm{L}^{-1}$, respectively (Fig. 3) while the average BOD values were observed as 466.4 and 475.4 $\mathrm{mg} \mathrm{L}^{-1}$ in CW-A and CW-B, respectively. CW-C control bed showed BOD range between 410.0 to $550.0 \mathrm{mg} \mathrm{L}^{-1}$ with an average value of $498.1 \mathrm{mg} \mathrm{L}^{-1}$.

The average $\mathrm{BOD}_{3}$ decrease at outlet amongst the three setup was most prominent in CW-B outlet (10 mm gravel filled). The $\mathrm{BOD}_{3}$ removal rate was observed as: $46.3,60.9$ and $62 \%$ in CW-A at $12 \mathrm{~h}, 24 \mathrm{~h}$ and $48 \mathrm{~h}$ HRTs respectively (Fig. S1). In CW-B (10 $\mathrm{mm}$ ), the removal rate was recorded as 48.1 and $62.2 \%$ at $12 \mathrm{~h}$ and $24 \mathrm{~h}$ HRTs, respectively while no further change was observed at $48 \mathrm{~h}$ HRT (Fig. S1). In CW-C, the $\mathrm{BOD}_{3}$ removal rate was found to be $45.2,57.1$ and $58.5 \%$ at $12 \mathrm{~h}, 24 \mathrm{~h}$ and $48 \mathrm{~h}$ HRTs, respectively. Using a similar setup comprising of a 2-stage SSVF CW and a SSHF CW, Job [38] obtained $\mathrm{BOD}_{5}$ 
removal rate of approximately $65 \%$. The $\mathrm{BOD}_{3}$ removal rate in our study showed an increase in all CW units (14.6\% in CW-A, $14.1 \%$ in CW-B and $11.8 \%$ in CW-C) when HRT was increased from 12 to $24 \mathrm{~h}$.

Chemical Oxygen Demand (COD) indirectly measures the amount of organic compounds in wastewater similar to BOD. It is also another pollution indicating parameter like BOD. During the study period, average concentration of COD recorded in dairy influent was $1,230.0 \pm 48 \mathrm{mg} \mathrm{L}^{-1}$ (Table S1). The average concentration of COD was found to be decreased by $56.5 \%$ at $12 \mathrm{~h}$, $64.6 \%$ at $24 \mathrm{~h}$ and $64.9 \%$ at $48 \mathrm{~h}$ HRT in CW-A. An increase of approximately $8 \%$ was observed in COD removal rate when HRT was increased from $12 \mathrm{~h}$ to $48 \mathrm{~h}$ in CW-A unit. In CW-B (10 mm gravel) removal was observed as 58.1, 66.5 and $67.4 \%$ at HRTs 12, 24 and $48 \mathrm{~h}$. In CW-C, the percent removal was minimum among all the three filter materials and was recorded as $54.6,62.3$ and $63.0 \%$ at $12 \mathrm{~h}, 24 \mathrm{~h}$ and $48 \mathrm{~h} \mathrm{HRT}$, respectively. Plant activities have essential role in organic matter degradation $[39,40]$. This occurs due to increase in plant biomass, leading to high amount of microbial development among the roots. Thus microbial degradation as well as biofilm formation is favoured leading to decrease in organic matter content of the wastewater.

From Table S1, it can be observed that maximum degradation of organic substances occurred in CW-B (10 mm gravel filled) at $24 \mathrm{~h}$ HRT. In a similar study [41] removal efficiency and removal of COD in gravel filled CW units were found in the range of 32.9 $50.4 \%$ and $7.4-20.6 \mathrm{~g} \mathrm{~m}^{-2} \mathrm{~d}^{-1}$ in VFCW, respectively in 4.9, 2.4 and $1.2 \mathrm{~d}$ of HRT. A study conducted by Abed [42] stated that hydraulic retention time (HRT) of $24 \mathrm{~h}$ is enough for removal of pollutants from wastewater by the activities of filter media as well as plants.

\section{Conclusions}

The constructed wetland involves diverse processes (physical, chemical \& biological) for removal of pollutants. Further, optimal operating parameters (i.e., water depth, hydraulic retention time and pollutant load) and wetland design also influence treatment performance of CW. The major findings of study are summarized as follows:

- No significant change in $\mathrm{pH}$ was observed with variation in HRT.

- The study showed higher removal of $\mathrm{NH}_{4}-\mathrm{N}$ and $\mathrm{BOD}_{3}$ with $48 \mathrm{~h}$ HRT in comparison to $12 \mathrm{~h}$ and $24 \mathrm{~h}$ HRTs. Removal rates of $\mathrm{NH}_{4}-\mathrm{N}$ and $\mathrm{BOD}_{3}$ were higher in gravel filled units compared to sand. The gravel has more porosity and provides more surface area for attachment of microbial community hence results in more pollutant removal.

- Sand filled CW unit showed 10\% higher removal of TSS compared to gravel filled units. Results indicate that change in HRT has least effect on TSS removal rate in all CW units. - Maximum DO increase of $5.8 \mathrm{mg} \mathrm{L}^{-1}$ was recorded in $20 \mathrm{~mm}$ gravel filled system at an HRT of $24 \mathrm{~h}$. Results showed that change in HRT did not influence DO however change in DO was affected due to filter media size.

- The maximum $\mathrm{PO}_{4}-\mathrm{P}$ removal (57.8\%) was achieved by 10 mm gravel filled unit at $48 \mathrm{~h}$ HRT. For better $\mathrm{PO}_{4}-\mathrm{P}$ removal synthetic and industrial products with high phosphorus sorption capacity and hydraulic conductivity can be explored as alternative substrates in CWs in case of poor absorptive media.

- During the study, change in removal rate of pollutants $\left(\mathrm{NH}_{4}-\mathrm{N}\right.$, $\left.\mathrm{BOD}_{3}, \mathrm{COD}\right)$ was significantly higher (12.2-18.6\%) when HRT was changed from $12 \mathrm{~h}$ to $24 \mathrm{~h}$. A slight increase $(<3 \%)$ in the removal rate of pollutants was observed when HRT was increased from $24 \mathrm{~h}$ to $48 \mathrm{~h}$. However this trend was not observed in case of TSS removal.

The study showed good removal of pollutants in all filter materials, however further study is recommended to validate findings on real-scale CW systems. We recommend assessment of planted vegetation for phytoremediation potential and biofilm formation on filter media in future studies for better understanding on pollutant removal mechanisms in CW.

\section{Acknowledgements}

Our sincere gratitude towards DBT, Ministry of Science and Technology, Government of India for supporting this work (Project No. BT/PR7545/BCE/8/999/2013). We are also thankful to Graphic Era Deemed to be University for providing necessary infrastructure for carrying out research work. Authors are thankful to Ms. Ankita Lal for manuscript proofreading.

This study was funded by DBT, Government of India through sanctioned research project (BT/PR7545/BCE/8/999/2013) to carry out research work. Partial funds and necessary infrastructure were provided by Graphic Era Deemed to be University for this work.

\section{Author Contributions}

D.M (Ph.D student) conducted all the experiments and wrote the manuscript. P.K.S (Professor) revised the manuscript. A.R (Associate Professor) wrote and revised the manuscript.

\section{References}

1. Britz TJ, Van Schalkwyk C, Hung Y. Treatment of dairy processing Wastewater. In: Wang LK, Hung Y-Tse, Lo HH, Yapijakis C, eds. Waste Treatment on the food processing Industry. $1^{\text {st }}$ ed.; CRC Press: Boca Raton, FL, USA, 2006. p.1-28.

2. Feng C, Sugiura N, Shimada S, Maekawa T. Development of a high performance electrochemical wastewater treatment system. J. Hazard. Mat. 2003;103(1-2):65-78.

3. Tetteh EK, Rathilal S. Application of Organic Coagulants in Water and Wastewater Treatment. Organic Polymers, Arpit Sand and Elsayed Zaki, IntechOpen; 2019. p. 1-20.

4. Tetteh EK, Rathilal S, Chetty M, Armah EK, Asante-Sackey D. Treatment of Water and Wastewater for Reuse and Energy Generation-Emerging Technologies in Water and Wastewater Treatment. IntechOpen; 2019. p. 1-23.

5. Kato K, Inoue T, Ietsugu $\mathrm{H}$, et al. Performance of six multi-stage 
hybrid wetland systems for treating high-content wastewater in the cold climate of Hokkaido, Japan. Ecol. Eng. 2013;51: 256-263.

6. Lei S, Bao-zehn W, Xiang-dong C, et al. Performance of subsurface-flow Constructed wetland in Southern China. J. Environ. Sci. 2004;16(3):476-481.

7. Vymazal J. Horizontal sub-surface flow and hybrid constructed wetlands systems for wastewater treatment. Ecol. Eng. 2005; 25(5):478-490.

8. Rousseau DP, Vanrolleghem PA, De Pauw N. Model-based design of horizontal subsurface flow constructed treatment wetlands: a review. Water Res. 2004;38(6):1484-1493.

9. Sharma PK, Takashi I, Kato K, Ietsugu H, Tomita K, Nagasawa T. Effects of load fluctuations on treatment potential of a hybrid sub-surface flow constructed wetland treating milking parlor waste water. Ecol. Eng. 2013;57:216-225.

10. Babatunde, AO, Zhao YQ. Phosphorus removal in laboratory-scale unvegetated vertical subsurface flow constructed wetland systems using alum sludge as main substrate. Water Sci. Technol. 2009;60(2), 483-489.

11. Sharma PK, Minakshi D, Rani A, Malaviya P. Treatment efficiency of vertical flow constructed wetland systems operated under different recirculation rates. Ecol. Eng. 2018;120:474-480.

12. Hasan MR, Rina C. Use of algae and aquatic macrophytes as feed in small-scale aquaculture: A review (No. 531). Food and Agriculture Organization of the United Nations (FAO). 2009.

13. Aljerf L. Advanced highly polluted rainwater treatment process. J. Urban Environ. Eng. 2018;12(1):50-58.

14. Hellström D, Jonsson L. Evaluation of small on-site wastewater treatment systems. Manag. Environ. Qual. 2006;17(6):728-739.

15. Priya SG, Brighu U. Comparison of Different Types of Media for Nutrient Removal Efficiency in Vertical Upflow Constructed Wetlands. Int. J. Environ. Eng. Mgt. 2013;4(5):405-416.

16. Grant WD, Long PE. Environmental microbiology. 1st ed.; Blackie and Son ltd, Glasgo, UK; 1981. p. 1-207.

17. Hunt BN. Determining the actual hydraulic retention time of a constructed wetland cell for comparison with the theoretical hydraulic retention time. [Thesis]. Athens: The University of Georgia; 2002.

18. Toet S, Van Logtestijn RS, Kampf R, Schreijer M, Verhoeven JT. The effect of hydraulic retention time on the removal of pollutants from sewage treatment plant effluent in a surface-flow wetland system. Wetlands 2005;25(2):375-391.

19. DeBusk TA, Reddy KR. Wastewater treatment using floating aquatic macrophytes: contaminant removal processes and management strategies. In: K.R Reddy and W.H Smith eds. Aquatic plants for water treatment and resource recovery, Mangolia Publishing Inc Orlando: FL; 1987.

20. Kadlec RH, Knight RL. Treatment wetlands. CRC Press/Lewis Publishers, Boca Raton, Florida. 1996.

21. Gajewska M, Skrzypiec K, Jóźwiakowski K, et al. Kinetics of pollutants removal in vertical and horizontal flow constructed wetlands in temperate climate. Sci. Total Environ. 2020;718: 137371

22. APHA. Standard Methods for Examination of Water and Wastewater. American Public Health Association WWA, Washington, D.C. 2005.
23. Butterworth E, Richards A, Jones M, Dotro G, Jefferson B. Assessing the potential for tertiary nitrification in sub-surface flow constructed wetlands. Environ. Technol. Reviews. 2016; 5(1):68-77.

24. Saeed, T., Sun, G. A review on nitrogen and organics removal mechanisms in subsurface flow constructed wetlands: Dependency on environmental parameters, operating conditions and supporting media. J. Environ. Mgt. 2012;112:429448.

25. Wu H, Zhang J, Ngo $\mathrm{HH}$, et al. A review on the sustainability of constructed wetlands for wastewater treatment: Design and operation. Bioresour. Technol. 2015;175:594-601.

26. Lee C, Fletcher T, Sun G. Nitrogen removal in constructed wetland systems. Eng. Life Sci. 2009;9(1):11-22.

27. Estela JM, Cerdà V. Flow analysis techniques for phosphorus: an overview. Talanta 2005;66(2):307-331.

28. Ye F, Li Y. Enhancement of nitrogen removal in towery hybrid constructed wetland to treat domestic wastewater for small rural communities. Ecol. Eng. 2009;35(7):1043-1050.

29. Minakshi D, Sharma PK, Rani A, Malaviya P. Treatment of Dairy Farm Effluent Using Recirculating Constructed Wetland Units. In: Advances in Health and Environment Safety. Springer: Singapore; 2018. p.57-66.

30. Akratos CS,Tsihrintzis VA. Effect of temperature, HRT, vegetation and porous media on removal efficiency of pilot-scale horizontal subsurface flow constructed wetlands. Ecol. Eng. 2007;29(2):173-191.

31. Bunce JT, Ndam E., Ofiteru ID, Moore A, Graham DW. A review of phosphorus removal technologies and their applicability to small-scale domestic wastewater treatment systems. Front. Environ. Sci. 2018;6:8.

32. Seo DC, Cho JS, Lee HJ, Heo JS. Phosphorus retention capacity of filter media for estimating the longevity of constructed wetland. Water Res. 2005;39(11):2445-2457.

33. Vymazal J. Constructed wetlands for wastewater treatment: five decades of experience. Environ. Sci. Technol. 2010;45(1):61-69.

34. Green M, Safray I, Agami M. Constructed wetlands for river reclamation: experimental design, start-up and preliminary results. Biores. Technol. 1996;55(2):157-162.

35. Arias CA, Del Bubba M, Brix H. Phosphorus removal by sands for use as media in subsurface flow constructed reed beds. Water Res. 2001;35(5):1159-1168.

36. Stearman GK, George DB, Hutchings LD. Removal of nitrogen, phosphorus and prodiamine from a container nursery by a subsurface flow constructed wetland. J. Bioremed. Biodegrad. 2012;S7:002.

37. Manios T, Stentiford EI, Millner P. Removal of total suspended solids from wastewater in constructed horizontal flow subsurface wetlands. J. Environ. Sci. Health Part A. 2003;38(6): 1073-1085.

38. Job GD. Treatment of medium strength industrial and agricultural effluents using reed bed treatment systems. [Thesis]. Birmingham: University of Birmingham; 1992.

39. Davies TH, Cottingham PD. The use of constructed wetlands for treating industrial effluent (textile dyes). Water Sci. Technol. 1994;29(4):227-232.

40. Zachritz WH, Fuller JW. Performance of an artificial wetlands 
filter treating facultative lagoon effluent at Carville, Louisiana. Water Env. Res. 1993;65(1):46-52.

41. Shutes RBE, Revitt DM, Mungur AS, Scholes LNL. The design of wetland systems for the treatment of urban run off. Water
Sci. Technol. 1997;35(5):19-25.

42. Abed SN. Effect of wastewater quality on the performance of constructed wetland in an arid region. [dissertation]. Birzeit: Birzeit University; 2012. 